\title{
Horace's hymn to Bacchus (Odes 2.19): poetics and politics
}

\author{
Stephen Harrison \\ The University of Oxford, Corpus Christi College
}

\footnotetext{
Bacchum in remotis carmina rupibus uidi docentem, credite posteri, Nymphasque discentis et auris capripedum Satyrorum acutas.

euhoe, recenti mens trepidat metu plenoque Bacchi pectore turbidum laetatur. euhoe, parce Liber, parce, graui metuende thyrso.
fas peruicacis est mibi Thyiadas uinique fontem lactis et uberes cantare riuos atque truncis lapsa cauis iterare mella;
fas et beatae coniugis additum stellis honorem tectaque Penthei disiecta non leni ruina, Thracis et exitium Lycurgi.
tu flectis amnes, tu mare barbarum, tu separatis unidus in iugis nodo coerces uiperino Bistonidum sine fraude crinis.

tu, cum parentis regna per arduum cohors Gigantum scanderet inpia, Rhoetum retorsisti leonis unguibus horribilisque mala,
}

I have seen Bacchus teaching his songs

Amid distant rocks - believe me, you who come after With the Nymphs as his pupils and the sharp ears Of the goat-footed satyrs.

5 Euhoe! My mind is atremble with fresh fear

And rejoices confusedly with a heart full of Bacchus: Euhoe! Spare me, Liber, spare me

You who are to be feared for your deadly thyrsus.

It is right for me to sing of the tireless Maenads, 10 The fountain of wine and rich streams of milk, And tell again of the honey flowing From hollow tree-trunks:

Right too to sing of the ornament of your blest consort Added to the constellations, and the house of Pentheus Scattered in no gentle collapse

And the destruction of Thracian Lycurgus.

You turn the course of rivers and the foreign sea,

You, wet with wine, in isolated hills

Bind harmlessly with a band of snakes

20 The hair of the women of Thrace.

You, when the impious squad of Giants climbed

Your father's realm through the heights,

Thrust back Rhoetus, terrible to behold

For your lion's claw and jaws, 


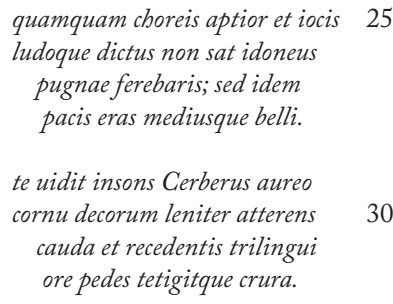

\author{
Though, said to be apter for dances, games \\ And sport, you were rumoured to be \\ Not fit enough for fighting: but you were the same \\ Central figure in both peace and war. \\ Cerberus saw you without trying to harm you, \\ Beautiful with your golden horn, gently rubbing you \\ With his tail, and as you departed he touched your \\ feet \\ And calves with his three-tongued mouth.
}

\section{Introduction}

This poem is a form of hymn to Bacchus, though its opening vision-scenario is unusual for a hymnic poem. ${ }^{2}$ Bacchus/ Liber, ${ }^{3}$ the Roman form of Dionysus, is of course a traditional god of poetry and a character in famous literary texts (some of which are duly drawn on for the accounts of his deeds in this poem, as we shall see later). In my view, it does not report a personal religious experience of Horace the real individual, though Fraenkel believed that it did: 'I think Horace means what he says. He did see Dionysus'; ; there is no reason to believe that this particular statement by the poet/narrator represents an actual event. This does not prevent any connection of the poem with religious texts; indeed Albert Henrichs has persuasively shown that this ode presents a number of formal elements which also occur in Dionysiac aretalogies, religious

1 All translations are my own; the text of 2.19 used is that of Harrison (2017), where the textual choices at lines 24 (horribilisque) and 31 (cauda) and the language of the poem in general receive fuller consideration. For the main literature on the poem in addition to commentaries [especially Nisbet; Hubbard (1978), Syndikus (2001)] see Pöschl (1973); Henrichs (1978); Batinski (199091); Davis (1991, 107-11); Koster (1994); Krasser (1995, 108-11; 119-27; 13841); Lowrie (1997, 205-10); Stevens (1999), and the complete list to 2006 in Holzberg (2007).

2 For a comparison with Callimachus'Hymn to Apollo cf. Krasser (1995,111-20).

3 I use these forms of the name interchangeably (as Horace's poem does).

4 Fraenkel $(1957,200)$. 
texts praising the god and enumerating his deeds and qualities. ${ }^{5}$ Accordingly, we need to analyse this poem as an example of the literary presentation of a divine encounter, as a kind of poetic consecration; ${ }^{6}$ Hesiod's Theogony, where the poet encounters the Muses who encourage him to sing (22-34), suggests that this encounter with Bacchus will have something to say about the poetics of the Odes, and we will find this to be true.

\section{Why Bacchus and not Apollo?}

It is interesting that Horace chooses Bacchus in this ode as his inspiring deity; in Callimachus' Aetia (fr.1 Pf.) and Virgil's sixth Eclogue this role is played by Apollo, and Apollo's association with the lyre would make him a natural god for this role in the Odes (cf. Odes 1.31.17-20). Like Apollo, Bacchus/ Dionysus is a god widely associated with different types of lyric poetry, especially dithyramb, ${ }^{7}$ and thus suits the lyric genre of the Odes; his role as the god of wine also helps to explain his presence in the Odes, given their frequent concern with the symposium and the consumption of wine as a theme and setting for poems ${ }^{8}$ (this is made more explicit in Odes 3.25, see below). As we shall see in section 4 below, there is also some affinity between the presentation of Bacchus in this poem and the poet's own selfframing as a lyric poet. Further, the poet is surely conscious of appropriating for his lyric a god whose primary generic association was with Greek tragedy, ${ }^{9}$ a rather different form of writing, and this link with a theoretically 'higher' literary genre perhaps reflects the poet's ambition as the collection of Odes

\footnotetext{
5 Henrichs $(1978,211-19)$.

6 For this theme in Greek and Roman poetry see still Kambylis (1965).

7 For Dionysus' link with dithyramb see e.g. Zimmermann (1992, 37-8).

8 For this theme see e.g. Davis (2007).

$9 \quad$ For an excellent summary of this connection see Easterling (1997).
} 
1-3 approaches Book 3 and the elevated Roman Odes. ${ }^{10}$ This rich literary history of Bacchus in Greek tragedy also makes a him a channel for a key technique of the Odes in appropriating material strongly associated with other literary kinds, 'generic enrichment' - see section 4 below.

This paper also argues that Bacchus is parallel to Augustus - that the selection of this god rather than Apollo is political as well as poetical. Since the foundation by the young Caesar of the temple of Palatine Apollo at Rome (dedicated in $28 \mathrm{BCE}$ ) as a celebration of the victory of Actium, the connection between Augustus and Apollo was perceived as a close one, even to the extent that rumours circulated that Apollo was Augustus' father (Suetonius Div.Aug. 92). As in Odes 1.2, where he suggests a link between the young Caesar and Mercury, Horace seems in 2.19 to be avoiding the obvious divine associations of Augustus with Apollo. Odes 1.2 and 2.19 appear to present a common strategy, to create a link between the young Caesar and a wider range of gods than just the established Apollo. This strategy is parallel to that of Vergil in the dedication of the Georgics, published probably in 29 $\mathrm{BCE}$ a few years before the Odes, which lists twelve traditional gods of agriculture and then turns to the young Caesar, seen as a potential new god who could oversee earth, sea or heaven (1.24-35). In both cases the divine links of the young leader are emphasised and extended. As we will see, the choice of Bacchus is not only an extension of divine links for the young Caesar; it is also an appropriation for Caesarian purposes of a god previously closely linked with the young Caesar's most dangerous rival and enemy, Marcus Antonius.

10 On this feature of the later poems of Odes 2 see the introduction to Harrison (2017). 


\section{Bacchus/Dionysus and politics}

\section{(a) identifying with Dionysus - Antony and afterwards}

It seems clear that while in Egypt with Cleopatra in the 30s BCE, Marcus Antonius chose to identify himself with the god Dionysus; ${ }^{11}$ this was largely because in Egypt Dionysus was widely linked with the god Osiris, the brother and husband of Isis (cf. e.g. Herodotus 2.42) and Cleopatra was keen to present herself as Isis, ${ }^{12}$ and there was a tradition of Greek and Greek/Egyptian kings identifying themselves with Dionysus which goes back to Alexander. ${ }^{13}$ In poetry written after the battle of Actium Antony's link with Dionysus, like his link with Hercules, seems to be transferred to the young Caesar, the future Augustus, and I would like to argue that this is a possible way of reading Odes 2.19; as we shall see, multiple links can be established between the young god Dionysus and the young semi-divine Caesar. ${ }^{14}$

One text written a few years before Horace's ode, and to which it seems to allude, is Tibullus $1.7(27 / 26 \mathrm{BCE})$. This is addressed to Messalla, ally of young Caesar at Actium and Antony's replacement as consul for 31, and its main section praises the qualities of the god Egyptian god Osiris, clearly identified with Bacchus (1.7.33-48):

\section{Hic docuit teneram palis adiungere vitem, Hic viridem dura caedere falce comam; Illi iucundos primum matura sapores Expressa incultis uva dedit pedibus.}

\footnotetext{
See Pelling (1988, 209), Śnieżewsk (1998).

2 See e.g. Takács (2011).

13 For some references see Woodman (1993, 213-15).

14 A similar and rewarding approach has been taken to the deployment of the figure of Bacchus in Vergil by Mac Góráin (2013). For a useful broader study of the cultural/political status of Bacchus at Rome see Fuhrer (2011).
} 
Ille liquor docuit voces inflectere cantu, Movit et ad certos nescia membra modos,

Bacchus et agricolae magno confecta labore Pectora tristitiae dissoluenda dedit.

Bacchus et adflictis requiem mortalibus adfert, Crura licet dura conpede pulsa sonent.

Non tibi sunt tristes curae nec luctus, Osiri, Sed chorus et cantus et levis aptus amor,

Sed varii flores et frons redimita corymbis, Fusa sed ad teneros lutea palla pedes

Et Tyriae vestes et dulcis tibia cantu Et levis occultis conscia cista sacris.

He it was who taught how to join the soft vine to stakes, He how to cut its green hair with the cruel pruning-hook:

For him the ripe grape first produced its joyous flavours, Pressed by the feet of the uncultivated.

That drink taught voices to modulate in singing, And moved limbs that knew not how to fixed measures.

Bacchus too granted that the heart of the farmer, worn out By great labour, should be freed from sorrow.

Bacchus too brings relief to afflicted mortals,

Though his legs clank with the sound of the cruel fetter.

Grim cares or grief do not befit you, Osiris,

But rather dancing and singing and the lightness of love,

But rather colourful flowers and a brow bound with ivy-berries

But a yellow dress spreading down to your soft feet,

And Tyrian purple clothes and the pipe sweet in song,

And the light box aware of its secret rites.

The hymnic repetition of pronouns is found in both this poem and Odes 2.19, but what makes it likely that Horace alludes to Tibullus is the couplet on Bacchus/Osiris' penchant for love and the dance: 2.19.25-6 quamquam choreis aptior et iocis $/$ ludoque dictus appears to pick up 1.7.43-4 Non tibi sunt tristes curae nec luctus, Osiri, / Sed chorus et cantus et levis aptus amor. 
This echo is of interest for the political aspect of Bacchus I have suggested for Odes 2.19. Given that Messalla had recently been a close lieutenant of the young Caesar in his victories over Antony in the East (as documented in this same poem), ${ }^{15}$ Tibullus' elegy can be seen like Horace's ode as an appropriation of Antony's identification with Bacchus for a leader on the opposite Caesarian side. Just as Tibullus suggests a clear encomiastic parallel between his addressee Messalla, bringer of peace and civilisation through his military achievements and their peaceful celebrations, and the god Osiris/Bacchus, bringer of peace and celebration through wine, ${ }^{16}$ so (I would like to suggest) Horace suggests a similar symbolic parallel between the young Caesar and Bacchus in this poem. The parallel way in which the two poets proceed shows the topical nature of great men identifying with Bacchus/ Osiris: both the young Caesar and the young Caesar's lieutenant can be identified with the god previously appropriated by Antony. Thus the capacity to identify oneself with a particular deity becomes part of the spoils of military success in the war of Actium and its Eastern aftermath. We shall see below that Hercules too receives much the same treatment as Bacchus in this respect, as another deity associated with Antony who becomes an important analogue for Augustus.

\section{(b) Bacchus as warrior, conqueror and liberator}

One aspect of Bacchus mentioned prominently by Horace in Odes 2.19 points in particular to the contemporary political context of the young Caesar and the recently concluded Roman civil wars. This is the role of Dionysus in the Gigantomachy, the traditional war of the gods and giants, in which he was

\footnotetext{
15 See e.g. Syme (1986, 207-10).

16 See e.g. Lee-Stecum $(1998,219)$.
} 
a prominent combatant, alluded to at 2.19.21-4 and much depicted in ancient art. ${ }^{17}$

This has political aspects since it is clear that the battle of Actium could be treated as a version of the Gigantomachy in which the young Caesar plays the role of the victorious Jupiter and his enemies Antony and Cleopatra become the defeated giants; this symbolism clearly underlies one of Horace's Roman odes (3.4.37-80) ${ }^{18}$ and the description of the battle of Actium on the Shield of Aeneas (Aeneid 8.671-713). ${ }^{19}$

This equivalence between Bacchus and Augustus becomes more explicit in other passages of Augustan poetry. At Odes 3.3.9-16 in another of the Roman odes we find Augustus compared to Pollux, Hercules, Bacchus and Quirinus (the divine name of Romulus) as an example of virtus or military courage:

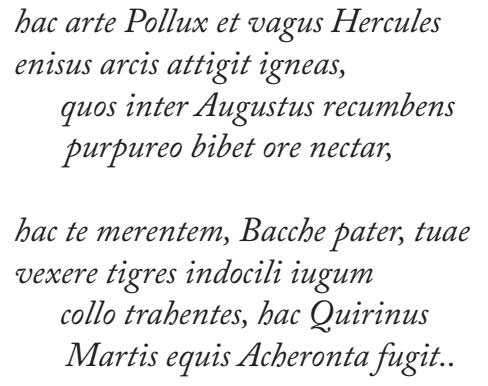

It was by this quality that Pollux and wandering Hercules Strove and touched the fiery heights:

Augustus, reclining with them,

Will drink nectar with crimson mouth,

It was by your deserving in this quality,

Father Bacchus, that your tigers bore you,

Drawing the yoke with untamed neck, by this quality

That Quirinus avoided Acheron on the horses of Mars...

\footnotetext{
17 See Vian (1988, 251-70).

18 see Lowrie (1997, 238-42).

19 see Hardie (1986, 97-109).
} 
Here again we find the warrior Bacchus, described as in the stories of his conquest of India, well known to poets of the Augustan period (cf. e.g. Vergil Aeneid 6.801-5 and Ovid Metamorphoses .4.21-2 as well as Odes 2.19); the Eastern victories of the god are clearly to be compared to those of the contemporary Roman leader, another way in which the battle of Actium and its following campaigns can be assimilated to the career of Bacchus as well as through the Gigantomachy.

The naming of Bacchus as Liber in Odes 2.19 points to a particular element of the identification of Augustus and Bacchus in the context of the battle of Actium which is especially important in propaganda terms. Peter Wiseman has suggested that in Roman culture Bacchus as Liber had long been associated with libertas, 'freedom', and the overthrow of tyrants, ${ }^{20}$ and Bacchus' name of Liber is specifically invoked in the famous opening of Horace Odes 1.37, the poet's celebration of the victory of Actium ( 1.37.1-2):

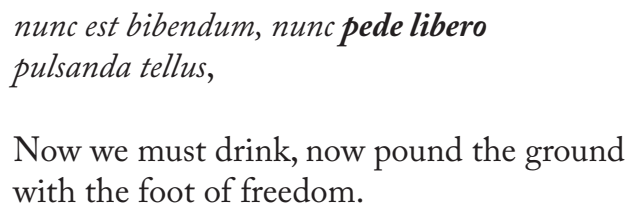

The 'foot of freedom' specifically identifies Antony and Cleopatra as tyrannical figures threatening Rome, who have now been defeated by the young Caesar; Horace and the supporters of Caesar should now celebrate this just victory. The parallel figures to Antony and Cleopatra in Odes 2.19 are the tyrants Pentheus and Lycurgus, who both wrongly resisted the power of the god Dionysus. The story of the Theban Pentheus, who is gruesomely torn apart by his own mother who is under the influence of Bacchus as a Bacchant, is famously told in Euripides' tragedy Bacchae, which is clearly referred to here (see further 4

20 Wiseman $(2004,64-70)$. 
below), while the story of Thracian Lycurgus, like Pentheus a monarch who refused to recognise the god's identity and was driven to death via madness, was narrated in the Lycurgus tetralogy of Aeschylus and the lost Lycurgus of the early Roman tragedian Naevius. ${ }^{21}$ So the figure of Liber in Odes 2.19 can be seen as a parallel to the young Caesar, who uses violence to establish proper order in the world and to defeat and destroy tyrannical figures who represent disorder and lack of respect for the divine character of their opponent. As we shall see, this includes a realistic assessment of the violence needed to achieve domination over one's enemies.

This divine identity of Liber/Bacchus/Dionysus is in fact just as important politically for Augustus as his military aspect. It is the other characteristic which Bacchus shares with Pollux, Hercules and Romulus/Quirinus: all in Roman thought are mortals who achieve divinity through their personal achievements. This is precisely how the Augustan poets come to conceive the status of Augustus himself: the young Caesar is close to the gods, being divi filius, son of a god, as the adoptive son of Julius Caesar who becomes Divus Iulius in $42 \mathrm{BCE}$, but he is not yet a god - that is a status he will achieve after death, after a life of service to mankind. Such in general is the presentation of the young Caesar in encomiastic poetic texts after Actium (e.g. Odes 3.3.9-16 (cited above), Vergil Georgics 1.24-42, 4.562, Aeneid 1.290), after an earlier period in the 30s BCE where straightforward association with gods was more prevalent (e.g. Odes 1.2.41-44, Vergil Eclogues 1.6-10, 42-3), which was understandable in a context where the young Caesar's opponents Antony and Cleopatra were following the Egyptian tradition of proclaiming themselves as living gods (see above).

21 For the Aeschylean tetralogy see Seaford 2005, for the Naevian play Spaltenstein 2014, 423-519. 
As support for the equivalence of Bacchus and Augustus we should look at the parallel hymn to Bacchus to be found in the next book of the Odes, and that I have already mentioned, 3.25:

Quo me, Bacche, rapis tui

plenum? Quae nemora aut quos agor in specus uelox mente noua? Quibus

antris egregii Caesaris audiar aeternum meditans decus

stellis inserere et consilio Iouis?

Dicam insigne, recens, adhuc

indictum ore alio. Non secus in iugis

exsomnis stupet Eubias,

Hebrum prospiciens et niue candidam

Thracen ac pede barbaro

lustratam Rhodopen, ut mibi deuio

ripas et uacuum nemus

mirari libet. O Naiadum potens

Baccharumque ualentium

proceras manibus uertere fraxinos,

nil paruum aut humili modo,

nil mortale loquar. Dulce periculum est,

o Lenaee, sequi deum

cingentem uiridi tempora pampino.

Where, Bacchus, are you taking me off to,

Full of you? What groves or caves are these I am driven to, Swift with strangeness of mind?

In which grottoes shall I be heard practising

To slot the eternal glory of Caesar

Into the stars and the council of Jupiter?

I shall proclaim something remarkable, something fresh

As yet unspoken by another's mouth. Just as in the hills

The sleepless Maenad is stupefied,

Gazing at the Hebrus and Thrace white with snow

And Rhodope, traversed

By foreign foot, so it is open to me, off the known way,

To wonder at the banks and empty grove.

You who hold sway over the Naiads and

The Bacchants who have strength 
To tear up lofty ash-trees with their hands, I shall say nothing small or of humble mode, Nothing mortal. It is a sweet peril, you of the wine-press, To follow the god who girds

His temples with the green leaf of the vine.

The reference to inserting Augustus in the council of the gods (line 6) clearly looks back in the same book to Odes 3.3, where, as we saw above, we find Augustus in the future sitting drinking ambrosia among the gods on Olympus, and the poem plainly refers to Horace's innovation in the Odes, using the traditional language of untrodden paths which looks back to Lucretius and Callimachus (lines 12-13). ${ }^{22}$ The second half of the poem compares the inspired poet to the devotee of Bacchus; here perhaps we can see again the parallel between Bacchus and Augustus, since the poet has already suggested that he is dedicated to Augustus and celebrating his achievements, and the god that the poet is to pursue could be the future god Augustus himself. The vine-leaf garland of the god could provide an interesting parallel to the triumph-garland of bay worn by Augustus as a great military conqueror in the triple triumph of $29 \mathrm{BCE}$.

\section{(c) full political allegorisation of Odes 2.19}

So far I have argued that the focus on Bacchus' military career and his aspect as a mortal who achieves divinity in Odes 2.19 points to his identification with Augustus. This type of allegorisation of the poem is not new ; indeed, J.A.Stevens, in an article published in 1999 has strongly pursued this mode of interpretation. ${ }^{23}$ Stevens argues not only that Horace's poem suggests that Bacchus' role in the Gigantomachy points to the

\footnotetext{
22 Lucr. 1.926-30 = 4.2-5, Call., Aetia fr.1 Pf.

23 Stevens (1999).
} 
role of the young Caesar in re-establishing political order in the context of a monstrous threat at the battle of Actium (as outlined above), but also goes on to argue that just as Bacchus is defending his father Jupiter's realm against the impious Giants, so Augustus should be seen as defending the realm of his late father Julius Caesar against the threat of Antony and Cleopatra. Stevens also suggests that the nymphs and satyrs of the opening stanza are symbols of the licentious coterie of followers of Antony and Cleopatra at Actium, while the scene in which Cerberus fawns on Dionysus scene is 'a meeting of Octavian and a sexually submissive Egypt'. ${ }^{24}$

Most elements here are convincing. The identification of Jupiter as Julius Caesar, the great father whose realm is defended through his warrior son, makes sense for the poet who proclaimed the young Caesar as the avenger of his dead father at Odes 1.2.44 Caesaris ultor, its indirect and symbolic form is understandable, given that Odes 1.2.44 is the only mention of Caesar in the whole of the Odes, and that both Horace and Vergil in the 20s BCE are circumspect about alluding to Julius Caesar. ${ }^{25}$ Although the legacy and name of Caesar was vital for the future Augustus, Julius Caesar's last years, where he was in effect an unconstitutional monarch who was assassinated by his own people and who received controversial and unparalleled divine honours at Rome in the last months of his life, ${ }^{26}$ did not present a model that the young Caesar wished to follow closely, and as Peter White has argued, ${ }^{27}$ this surely explains

24 Stevens (1999, 292).

25 For Vergil's similar reticence in this same period see the highly ambivalent allusion to Caesar as protagonist of civil war at Aeneid 6.830-35 (where notably he is not named), the only sure allusion to Caesar in Vergil apart from the reference to his death at Georgics 1.466; for me, Aeneid 1.286-90 must be Augustus not Caesar (see Harrison 1996).

26 See Gradel (2002, 54-72).

27 White (1988). 
why Julius Caesar is largely absent from or only indirectly alluded to in Augustan poetry. The idea that the fawning hound Cerberus represents a submissive Egypt also has its attractions, since the theriomorphic dog-god Anubis is twice presented amongst the defeated forces at Actium in Augustan poetry (cf. Propertius 3.11.41, Vergil Aeneid 8.698), though the suggestion of a specifically sexual element is perhaps a little fanciful; but the notion that the nymphs and satyrs of the opening stanza represent the debauched followers of Antony and Cleopatra at Actium is less persuasive. As we shall see, this mixed-gender group of Bacchus' auditors finds a more persuasive symbolic match in the boys and girls who are the explicit addressees of Odes 3.1.

One element worth considering here is how far a comparison with Bacchus can reflect an interestingly complex view of the young Caesar. The ruler of Rome is being compared to a great and mighty god, but also to a god of unpredictable violence, who can exercise his devastating powers of destruction not only against his father's enemies in the Gigantomachy, but also against members of his own family in the plot of Euripides' Bacchae, where he causes the death of his cousin Pentheus and ruins the life of his mother Agave (who kills her son in Bacchic frenzy) and grandparents Cadmus and Harmonia (who are transformed into snakes in the play's fragmentary conclusion). Here perhaps we can see some reflection by the poet on the darker side of autocracy and personal power, carefully concealed in a symbolic parallel; the young Caesar was content to agree to the legalised killing of many distinguished Romans (e.g. Cicero) in the proscriptions of $43 \mathrm{BCE}$, and even in the campaign of Actium he was happy to destroy his former brother-in-law Marcus Antonius. We may compare the complex depiction of Aeneas in Vergil's Aeneid, whose undoubted violent side in establishing a proto-Roman foothold in Italy for his Trojans may reflect the violence which his distant descendant Augustus 
needed to apply in his establishment of the monarchical rule of the principate. ${ }^{28}$

\section{Bacchus and poetics in Odes 2.19}

I now want in my final section to turn to the issue of poetics. If this poem talks symbolically about key political themes of Horace's time, can we also identify some key elements of contemporary poetics? I would like to argue that we can, and that in particular we can see the figure of Bacchus as representing not only Augustus as god and conqueror but also Horace himself as the powerful and controlling poet of a particular type of lyric in the Odes, a type which encompasses material normally associated with other literary genres.

\section{(a) Bacchus, poetic memory and generic enrichment}

As already suggested, part of Horace's account of Bacchus in this poem is plainly drawn from the Bacchae of Euripides $(2.19 .9-16):{ }^{29}$

\footnotetext{
fas peruicacis est mibi Thyiadas uinique fontem lactis et uberes cantare riuos atque truncis lapsa cauis iterare mella;

fas et beatae coniugis additum consort stellis honorem tectaque Penthei

disiecta non leni ruina,

Thracis et exitium Lycurgi.
}

\footnotetext{
It is right for me to sing of the tireless Maenads,

10 The fountain of wine and rich streams of milk, And tell again of the honey flowing From hollow tree-trunks:

Right too to sing of the ornament of your blest Added to the constellations, and the house of [Pentheus

15 Scattered in no gentle collapse, And the destruction of Thracian Lycurgus.
}

28 See e.g. Harrison (1991, 215).

29 It is not unlikely that a lost intermediary Latin tragic version of the Pentheus story such as Pacuvius' Pentheus or Accius' Bacchae also plays a role here, as seems probable for the non-Euripidean details of Vergil Aeneid 4.469-73 =[see Fernandelli (2002)]; for the 'missing link' of Roman republican tragedy as an influence on extant Augustan poetry see e.g. Griffin (1985, 198-210). 
The simultaneous streams of wine, milk and honey here (10-12) clearly recall those stimulated by the divine presence

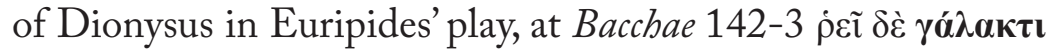

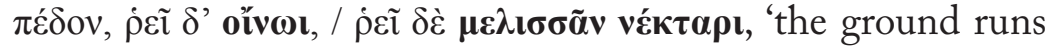
with milk, runs with wine, runs with the nectar of bees', and Bacchae 707-11:

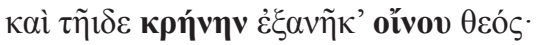

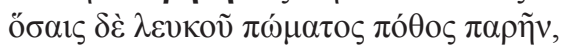

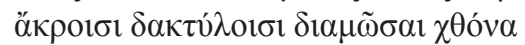

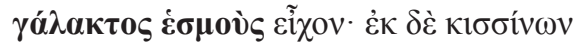

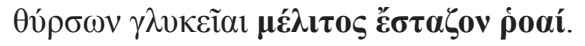 \\ And with this the god released a spring of wine: \\ And all those who had a desire for the white drink, \\ Clawing the ground with the tips of their fingers \\ Had swarms of milk: and from their thrysi \\ Of ivy-wood flowed sweet streams of honey.
}

Likewise, the account of Dionysus' destruction of Pentheus' palace (14-15, especially tectaque Penthei) picks up Bacchae 587-

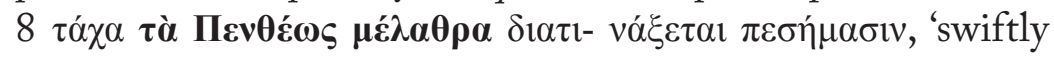
will the palace of Pentheus / be shaken with falls'; the choice of the verb disiecta at 2.19.15 also looks to the sparagmos of Pentheus by his female relatives which forms the tragic climax of Euripides' play. ${ }^{30}$

These echoes would have been obvious to the more learned readers of Horace's poem, which thus evidently repeats the material of a famous literary text in a genre other than that of lyric. This repetition seems to be marked explicitly in our text: at line 12 the verb iterare, 'repeat', surely points to the fact that Horace is telling the story of the Bacchae once more, an example of the 'poetic memory' influentially argued for by Gian Biagio Conte; we may compare with this Horatian iterare the famous

30 Cf. Horace Satires 1.4.62 inuenies etiam disiecta membra poetae, Seneca Phaedra 1256 disiecta ... membra laceri corporis. 
Though I would not go all the way with Helmut Krasser, who has argued that Bacchus represents the prime model for the lyric poet throughout Odes 1-3, ${ }^{33}$ it is difficult not to link Bacchus here with the self-description of the poet of the Roman Odes.

This parallel between Horace and Bacchus can be taken further if we consider the penultimate stanza of 2.19 (25-8):

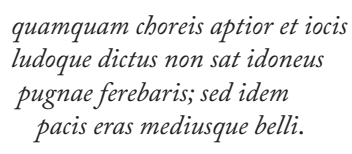

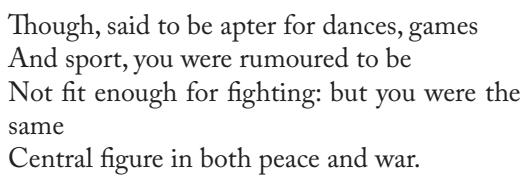

Here, I think, we can see a clear parallel between the Bacchus of Odes 2.19 and Horace's self-descriptions as a poet in other contexts. Bacchus here is concerned with ioci (25) and ludus (26), but also ready for participation in warfare. This is surely analogous to Horace, who in the very first poem of this same second book of Odes has defined himself as being principally a poet of ioci ( 2.1 .37 relictis ... iocis), and who in the first book of Epistles defines the Odes and the accompanying lifestyle as ludus and ludere (cf. Ep.1.14.36 nec lusisse pudet, sed non incidere ludum), but who like Bacchus is prepared to engaged in the poetry of war when needed: we recall Odes 2.7 in this same book, where Horace looks back on his time as a soldier at Philippi, and the general broad range of the Odes, which deal with such a wide range of topics, from civil war and Actium to symposia and casual love. The Horace of the Odes, like the Bacchus of Odes 2.19 , is a poetic figure who can cover both war and peace and who can stand at the centre of both as the controlling poet, just as the Horace of real life can move from a warlike career as a soldier at Philippi to the peaceful role of a symposiastic amicus of the great at Rome, and can represent himself as pleasing those who lead Rome in both peace and war (Ep. 1.20.23 me primis urbis belli placuisse domique).

\footnotetext{
33 Krasser (1995, 92-149). [for my reservations see Harrison (1998)].
} 


\section{Conclusion}

This paper has argued that Odes 2.19 presents Bacchus both as a parallel for the young Caesar in his role as bringer of moral order through the destruction of tyrants, reflecting the Caesarian appropriation of Dionysiac identification from Marcus Antonius after Actium, and as a parallel for Horace as author of the Odes: Odes 2.19's description of Bacchus' wide-ranging actions and deeds suggest the range of topics covered by the lyric poet Horace himself, including the self-conscious incorporation of material from another genre associated with this god (Attic tragedy), which provides evidence for an important technique of the Odes in general (generic enrichment). The encomiastic link of Bacchus and Augustus is not without interesting ideological tensions: Bacchus' twin functions of bringer of vinous pleasure and instigator of chaotic violence (often closely connected in mythology) could reflect the uneasy marriage of violence and order in the pre-Actium career of Augustus. In some sense, too, the figure of Bacchus in Odes 2.19 could be said to be a site of contest between poet and princeps: should the reader look more to the parallel between the lyric poet and a suitable patron god of his immortal poetry, or to that between the divine conqueror and the mortal victor and ruler who is ultimately destined for the status of a god? ${ }^{34}$

\section{Bibliography}

Batinski E.E. 1990-91. "Horace's rehabilitation of Bacchus." Classical World 84: 361-78.

Conte, G.B. 1986. The Rhetoric of Imitation. Ithaca, N.Y.: Cornell University Press.

34 My thanks to Paulo Martins for his kind invitation to USP and for his editorial patience. 
Davis, G. 2007. "Wine and the Symposium," in The Cambridge Companion to Horace, ed. S.J.Harrison, 207-220. Cambridge: Cambridge University Press.

1991. Polyhymnia: The Rhetoric of Horatian Lyric Discourse. Berkeley and London: California University Press.

Easterling, P.E. 1997. "A Show for Dionysus." In: The Cambridge Companion to Greek Tragedy, ed. P. E. Easterling, 36-53. Cambridge: Cambridge University Press.

Fernandelli, M. 2002. "Come sulle scene: Eneide IV e la tragedia". Quaderni del Dipartimento di filologia A. Rostagni. 1: 141-211.

Fraenkel, E. 1957. Horace. Oxford: Oxford University Press.

Fuhrer, T. 2011. "Inszenierungen von Göttlichkeit. Die politische Rolle von Dionysos/Bacchus in der römischen Literatur." In: A Different God? Dionysos and Ancient Polytheism, ed. R.Schlesier, 373-89. Berlin and Boston: De Gruyter.

Gradel, I. 2002. Emperor worship and Roman religion. Oxford: Oxford University Press.

Griffin, J. 1985. Latin Poets and Roman Life. London: Duckworth.

Hardie, P. 1986. Virgil's Aeneid: Cosmos and Imperium. Oxford: Oxford University Press.

Harrison, S.J. 1991. Vergil: Aeneid 10. Oxford: Oxford University Press. 1996. “Vergil Aeneid 1.286: Julius Caesar or Augustus ?', Papers of the Leeds International Latin Seminar 9: 127-33. 70: $672-6$. 1998. Review of H.Krasser, Horazische Denkfiguren. Gnomon 2007. Generic Enrichment in Vergil and Horace. Oxford: Oxford University Press.

Press.

. 2017. Horace Odes Book II. Cambridge: Cambridge University

Henrichs, A. 1978. "Horaz als Aretaloge des Dionysos. Credite posteri.' Harvard Studies in Classical Philology 82: 203-211.

Holzberg, N. 2007. Horaz: Eine Bibliographie, Munich [self-published]. [online at <http://www.niklasholzberg.com/Homepage/Bibliographien. html>, accessed 22.1.2016] 
Kambylis, A. 1965. Die Dichterweihe und ibre Symbolik, Heidelberg: Winter.

Koster, S., 1994. "Quo me Bacche rapis? (Hor.carm.3.25 und 2,19)", in Horaz-Studien, ed. S.Koster. 51-70. Erlangen: Universitätsbibliothek Krasser, H. 1995. Horazische Denkfiguren. Göttingen: Vandenhoeck and Ruprecht.

Lee-Stecum, P. 1998. Power-Play in Tibullus. Cambridge: Cambridge University Press.

Lowrie, M. 1997. Horace's Narrative Odes. Oxford: Oxford University Press.

Mac Góráin, F. 2013. "Virgil's Bacchus and the Roman Republic.” In Augustan Poetry and the Roman Republic, ed. D. Nelis and J. Farrell, 12445. Oxford: Oxford University Press.

Nisbet, R.G.M. and Hubbard, M. 1978. A Commentary on Horace: Odes II. Oxford: Oxford University Press.

Pelling, C.B.R. 1988. Plutarch: Life of Antony. Cambridge: Cambridge University Press.

Pöschl, V. 1973. "Die Dionysosode des Horaz (c. 2, 19)”. Hermes 101: 208-230.

Seaford, R.2005. "Mystic light in Aeschylus' Bassarai." Classical Quarterly 55: 602-606.

Śnieżewski, S. 1998. "Divine connections of Marcus Antonius in the years 43-30 BC.” Grazer Beiträge 22: 129-144.

Spaltenstein, F.2014. Commentaire des fragments dramatiques de Naevius. Bruxelles: Latomus.

Stevens, J.A. 1999. "Seneca and Horace: Allegorical Technique in Two Odes to Bacchus (Hor."Carm." 2.19 and Sen. "Oed." 403-508)." Phoenix 53: 281-307.

Syme, R. 1986. The Augustan Aristocracy. Oxford: Oxford University Press. Syndikus, H. P. 2001. Die Lyrik des Horaz [2 vols; 3rd ed]. Darmstadt: Wissenschafliche Buchgesellschaft.

Takács, S. 2011. “Cleopatra, Isis, and the formation of Augustan Rome.”In Cleopatra: a sphinx revisited, ed. Margaret Melanie Miles, 78-95. Berkeley and London: University of California Press. 
Vian, F, 1988. "Gigantes", Lexicon Iconographicum Mytologiae Classicae IV: 191-270.

White, P. 1988. “Julius Caesar in Augustan Rome', Phoenix 42: 334-356.

Wiseman, T.P. 2004. The Myths of Rome. Exeter: University of Exeter Press.

Woodman A.J. 1993. Velleius Paterculus; The Caesarian and Augustan Narrative (2.41-93). Cambridge: Cambridge University Press.

Zimmermann, B. 1992 Dithyrambos: Geshichte einer Gattung. Göttingen: Vandenhoeck and Ruprecht. 